\title{
4-1BB (CD137) signals depend upon CD28 signals in alloimmune responses
}

\author{
Eun-A Lee ${ }^{1}$, Jeong-Eun Kim ${ }^{1}$, \\ Jae Hee Seo ${ }^{3}$, Byoung Se Kwon ${ }^{1}$, \\ Seok Hyun Nam ${ }^{5}$, Byungsuk Kwon ${ }^{1,2 *}$ \\ and Hong Rae Cho $0^{1,4,5,6_{*}}$ \\ ${ }^{1}$ The Immunomodulation Research Center \\ ${ }^{2}$ Department of Biological Science \\ University of Ulsan \\ Ulsan 680-742, Korea \\ ${ }^{3}$ Department of Pathology \\ ${ }^{4}$ Department of Surgery and Biomedical Research Center \\ Ulsan University Hospital \\ College of Medicine, University of Ulsan \\ Ulsan 682-060, Korea \\ ${ }^{5}$ Department of Biological Science \\ Ajou University \\ Suwon 443-749, Korea \\ ${ }^{6}$ Corresponding author: Tel, 82-52-250-7100; \\ Fax, 82-52-236-5417; E-mail, hrcho@uuh.ulsan.kr \\ *These two authors share a corresponding authorship.
}

Accepted 23 September 2006

Abbreviations: AICD, activation-induced cell death; CFSE, 5,6carboxylfluorescein diacetate succinimidyl ester; MLR, mixed leukocyte reaction; MST, mean survival time; TCR, T-cell receptor; WT, wild-type

\begin{abstract}
Our previous study has demonstrated that there is a significant delay of Balb/c cardiac allograft rejec tion in the C57BL/6 4-1BB-deficient knockout recipient. In this study, we examined the effect of combined blockade of the 4-1BB and CD28 costimulatory pathways on cardiac allograft rejection in the $\mathrm{C} 57 \mathrm{BL} / 6 \rightarrow \mathrm{Balb} / \mathrm{c}$ model. A long-term cardiac allograft survival was induced in CD28/4-1BBdeficient mice ( $>100$ days survival in 3 of 4 mice), which was comparable with CD28-deficient mice ( $>$ 100 days survival in 2 of 5 mice; $P<0.2026$ ). There was no long-term cardiac allograft survival in either wild-type (WT) or 4-1BB-deficient mice, even though 4-1BB-deficient recipients showed a significant delay of cardiac allograft rejection than WT mice. An in vitro mixed leukocyte reaction (MLR) assay showed that 4-1BB-deficient and WT mouse T cells had a similar responsiveness to allostimulation,
\end{abstract}

whereas CD28- and CD28/4-1BB-deficient mouse T cells had a defective responsiveness to allostimu lation. Furthermore, 4-1BB-deficient mice showed a similar CTL but an elevated $A b$ response against alloantigens as compared to WT mice, and the alloimmune responses of 4-1BB-deficient mice were abrogated in the CD28-deficient background. Overall, these results indicate that the CD28 costimu latory pathway plays a major role in the alloimmune response and that 4-1BB signals are dependent upon CD28 signals.

Keywords: antibody formation; antigens; CD28; CD137 antigen; graft rejection; mice, knockout

\section{Introduction}

Because $T$ cells are the primary mediators of allograft rejection (Hall, 1991; Rosenberg and Singer, 1992), much effort has been directed at designing therapeutics that specifically block the initial activation of $T$ cells in allograft recipients. T cell activation is dependent upon signals generated by the T-cell receptor (TCR) when it recognizes a peptide presented by a MHC molecule. However, the TCR signal fails to fully activate T cells in the absence of a second, costimulaory signal (Schwartz, 1990). A number of receptor/ligand pairs expressed on the surface of T cells and APCs are capable of providing the necessary costimulatory signal.

The 4-1BB/4-1BB ligand (4-1BBL) and CD28/ CD80/CD86 pathways are two well characterized costimulatory pathways. Both pathways are critical in the activation and maturation of T cells, and thus have been explored as therapeutic targets in a number of transplant models. Blockade of the CD28 costimulatory pathway has been shown to prevent acute allograft rejection and to induce donor-specific tolerance in several murine transplant models (Turka et al., 1992; Pearson et al., 1994; Sayegh et al., 1995). Treatment with CTLA4-Ig, a recombinant fusion protein containing the extracellular domain of CTLA-4 and a $F c$ portion of human $\lg _{1}$, can inhibit proliferation of alloreactive $T$ cells and induce anergy in those cells that do proliferate despite CD28 blockade (Judge et al., 1996). Importantly, activationinduced cell death (AICD) is required for CTLA4Ig-medaited T-cell tolerance. Agents that increase AICD, such as rapamycin, promote tolerance by 
blockade of the CD28/CD40 costimulatory pathways (Li et al., 1999). Other observations also support AICD as a prerequisite for the generation of peripheral tolerance to allografts by costimulatory blockade (Dai et al., 1998; Wells et al., 1999). Recently, a high-affinity variant of CTLA4-Ig has been developed and has shown significant prolongation of renal allograft survival in a pre-clinical primate model (Larsen et al., 2005) and human patients (Vincenti et al., 2005).

4-1BB (CD137) is a costimulatory member of the TNF receptor (TNFR) family expressed on activated T cells, some dendritic cells (DCs) and activated NK cells (Vinay and Kwon, 1998; Kwon et al., 2000; 2002a; 2003). 4-1BBL is expressed on activated APCs, such as B cells, macrophages and DCs (Goodwin et al., 1993; Pollok et al., 1994; DeBenedette et al., 1997; Futagawa et al., 2002; Wilcox et al., 2002a). Interactions of 4-1BB/4-1BBL were suggested to be involved in alloimmune responses, since both 4-1BB and 4-1BBL transcripts were expressed in rejecting mouse cardiac allografts (Tan et al., 2000). Indeed, blockade of the 4-1BB costimulatory pathway was shown to be effective in prevention of $\mathrm{CD}^{+}{ }^{+} \mathrm{T}$-cell-mediated small bowl rejection (Wang et al., 2003). We also demonstrated that there was a significant delay in cardiac allograft rejection in 4-1BB-deficient mice (Cho et al., 2004). Moreover, anti-4-1BBL mAb induced a long-term allograft survival in 2 out of 5 allograft recipients. It seems that, even though anti-4-1BBL mAb could not block proliferation of $\mathrm{T}$ cells initially, it was effective in decreasing the number of alloreactive $T$ cells at the later stage of alloimmune responses (Cho et al., 2004). In the chronic graft-versus-host disease (cGVHD) setting, stimulation of 4-1BB was highly effective in preventing and curing CGVHD by inducing AICD of pathogenic donor $\mathrm{CD}^{+} \mathrm{T}$ cells (Kim et al., 2005).

Some evidence suggests that 4-1BB might play a role in the immune response later than CD28, and possibly functions to perpetuate the immune response (Kim et al., 1998; Rothstein et al., 2003). Based on this and other facts that resistance of some $\mathrm{CD}^{+} \mathrm{T}$ cells to treatment with CTLA4-Ig is the main reason for rejection of allografts in several models (Newell et al., 1999; Trambley et al., 1999) and that $4-1 \mathrm{BB}$ is a key costimulatory molecule for $\mathrm{CD}^{+} \mathrm{T}$ cells, we hypothesized that there could be a synergistic effect of combined blockade of the CD28/4-1BB costimulatory pathways on prolongation of cardiac allograft survival.

\section{Materials and Methods}

\section{Mice}

Breeding pairs of wild-type (WT) Balb/c $\left(\mathrm{H}-2^{\mathrm{d}}\right)$ and
C57BL/6 $\left(\mathrm{H}-2^{b}\right)$ mice were purchased from the Jackson Laboratory (Bar Habor, ME). CD28-deficient (Lucas et al., 1995) and 4-1BB-deficient (Kwon et al., 2002b) mice were backcrossed to Balb/c mice for more than 10 generations, and CD28/4-1BBdeficient mice were generated by crossing CD28deficient with 4-1BB-deficient mice (Vinay et al., 2003). All mice were bred in the University of Ulsan Animal Facility. Mice were maintained in a dedicated, specific pathogen-free facility in microisolator cages. We performed all animal experiments following the "Principles of Laboratory Animal Care" (NIH publication No. 86-23).

\section{Heterotopic heart transplantation}

Vascularized donor heart grafts from $\mathrm{C} 57 \mathrm{BL} / 6$ mice were transplanted into WT, CD28-deficient, 4-1BBdeficient, and CD28/4-1BB-deficient Balb/c mice, essentially as previously described (Corry et al., 1973). In brief, donor hearts were harvested and placed in cold PBS until transplanted. The recipient mice were anesthetized, and the aorta and pulmonary artery of the donor hearts were sutured to the recipient aorta and inferior vena cava, respectively, end-to-side using 10-0 suture silk. Graft survival was monitored by daily abdominal palpation. Rejection was considered complete when cardiac contraction had completely ceased. This was confirmed by direct visualization of grafted hearts.

\section{Immunohistochemical analysis}

Grafted C57BL/6 hearts were harvested 7 days after transplant. Immunohistochemistry was done as described previously (Kim et al., 2006). In brief, the tissues were embedded in optimal cutting temperature (OCT) compound (Sakura Finetek, Torrence, CA) and snap-frozen in liquid nitrogen. Sections (8- $\mu \mathrm{m}$ thick) were air-dried, fixed with acetone, and stained sequentially with anti-CD3 mAb, biotyinylated rabbit anti-rat IgG, streptavidin-horseradish peroxidase (HRP), and a substrate for HRP (BD Biosciences Pharmingen, San Diego, CA).

\section{In vitro mixed leukocyte reaction (MLR)}

To prepare APC-enriched populations, C57BL/6 splenocytes were incubated in $10-\mathrm{cm}$ plates at $37^{\circ} \mathrm{C}$ for $2 \mathrm{~h}$ to remove non-adherent lymphocytes. The adherent cells were further incubated overnight at $37^{\circ} \mathrm{C}$. These APCs were irradiated (30 Gy) before used to stimulate $T$ cells of Balb/c origin. Balb/c $T$ cells were prepared from spleen and lymph node cells using nylon wool column (Wako Chemical, Tokyo, Japan) after red blood cell lysis on Tris-buffered ammonium chloride for $3 \mathrm{~min}$. For an in 
vitro MLR, responder Balb/c T cells $\left(1 \times 10^{5} /\right.$ well $)$ and stimulator C57BL/6 APCs $\left(5 \times 10^{5} /\right.$ well) were added in triplicate into 95-well plates in a final volume of $200 \mu \mathrm{l}$. The cultures were incubated at $37^{\circ} \mathrm{C}$ in a humidified air containing $5 \% \mathrm{CO}_{2}$ for $3 \mathrm{~d}$. Proliferation on day 3 was assessed by pulsing with 1 $\mu \mathrm{Ci}\left[{ }^{3} \mathrm{H}\right]$-thymidine (Amersham Pharmacia Biotech, Piscataway, NJ) added during the last $12 \mathrm{~h}$.

\section{Enzyme-linked immunosorbent assay (ELISA)}

Supernatants from MLR cultures were harvested and the concentrations of IFN- $\gamma$ and IL-2 were determined according to the manufacturer's protocol (Pierce Endogen, Rockford, IL).

\section{Measurement of allospecific lgG}

Allospecific $\lg G$ was measured as described previously (Sakurai et al., 2000). In brief, serum was harvested from the tail vein at days $0,7,14,21$ and 28 after transplantation. EL4 cells $\left(\mathrm{H}-2^{b}\right)$ were incubated with each serum on ice. After $20 \mathrm{~min}$, the cells were washed and then incubated with FITCconjugated anti-mouse IgG (BD Pharmigen Biosciences). After washing two times, the fluorescence intensities were monitored using a FACS and data were analyzed using Cellquest software (BD Pharmingen Biosciences).

\section{In vivo CTL assay}

An in vivo CTL was modified as described previously (Coles et al., 2002). In brief, C57BL/6 mice were irradiated with $8 \mathrm{~Gy}$ and received $2 \times 10^{7}$ of WT, CD28-, 4-1BB-, or CD28/4-1BB-deficient splenocytes. After $5 \mathrm{~d}$, target cells were prepared from naïve C57BL/6 and Balb/c splenocyte suspensions by lysing erythrocytes using Tris-buffered ammonium chloride for $3 \mathrm{~min}$. After washing, C57BL/6 cells were labeled with $2.5 \mu \mathrm{M}$ of 5,6-carboxyfluorescein diacetate succinimidyl ester (CFSE) (CFSE ${ }^{\text {high }}$ ) and used as target cells, and Balb/c cells were labeled with $0.25 \mu \mathrm{M}$ of CFSE (CFSE ${ }^{\text {low }}$ ) and used as control target cells. For reference cells (syngeneic cells), Balb/c splenocytes were labeled with a high or a low concentration of CFSE. For i.v. injection, an equal number of cells from each population was mixed together, such that each mouse received a total of $20 \times 10^{6}$ cells in $150 \mu \mathrm{l}$ of PBS. Cells were injected into the immunized WT, CD28-deficient, 4-1BBdeficient, and CD28/4-1BB-deficient mice. Four hours later, splenocytes were harvested and analyzed by FACS, and each population was detected by their differential CFSE fluorescence intensities (Kim et al., 2006). To calculate allospecific lysis, the following formula was used: ratio $=$ (percentage $\mathrm{CFSE}^{\text {low }} /$ per- centage CFSE $\left.{ }^{\text {high }}\right)$; percentage allospecific lysis = [1(ratio syngeneic/ratio allogeneic) $\times 100]$.

\section{Statistical analysis}

Kaplan-Meier survival graphs were constructed and log-rank comparisons of experimental groups were used to calculate $P$ values. Significant differences between experimental groups in MLR and ELISA were analyzed using Student's $t$ test. Differences were considered significant at $P<0.05$.

\section{Results}

To investigate the effect of $4-1 B B / C D 28$ costimulatory blockade on cardiac allograft survival, we transplanted fully MHC-mismatched C57BL/6 $\left(\mathrm{H}-2^{b}\right)$ cardiac allografts into WT, CD28-deficient, 4-1BBdeficient, or CD28/4-1BB-deficient Balb/c $\left(\mathrm{H}-2^{d}\right)$ recipients. As shown in the Balb/c $\rightarrow$ C57BL/6 model (Cho et al., 2004), the 4-1BB defect was associated with a significant delay in cardiac allograft rejection (Figure 1); the mean survival time (MST) were 8 and $20 \mathrm{~d}$ in WT and 4-1BB-deficient mice, respectively ( $n$ $=7 ; P<0.0017)$. In CD28-deficient mice, the MST was $45 \mathrm{~d}(n=5 ; P<0.002)$ and 2 out of 5 mice had a long-term cardiac allograft survival ( $>100 \mathrm{~d}$ ). There was a long-term allograft survival in 3 out of 4 mice in CD28/4-1BB-deficient mice $(n=4 ; P=$ $0.0045)$. Statistical analysis revealed no significant difference in allograft survival between CD28-deficient and CD28/4-1BB-deficient mice, indicating that combined blockade of CD28/4-1BB might have no synergistic effect on cardiac allograft rejection. Immunohistological analysis at day 7 after transplan-

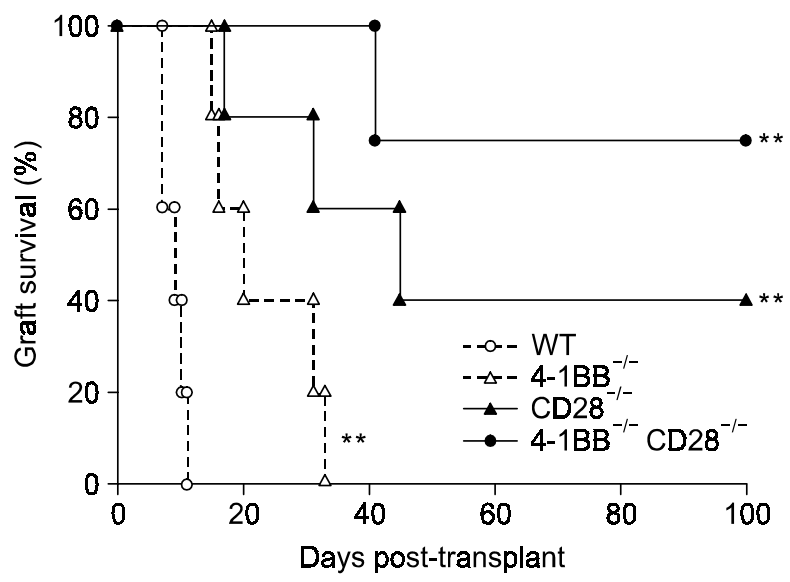

Figure 1. Survival of cardiac allogaft survival. Vascularized C57BL/6 cardiac grafts were transplanted into WT, CD28-, 4-1BB-, and CD28/ 4-1BB-deficient Balb/c mice. ${ }^{* *} P<0.01$, between WT and the indicated mouse group. 

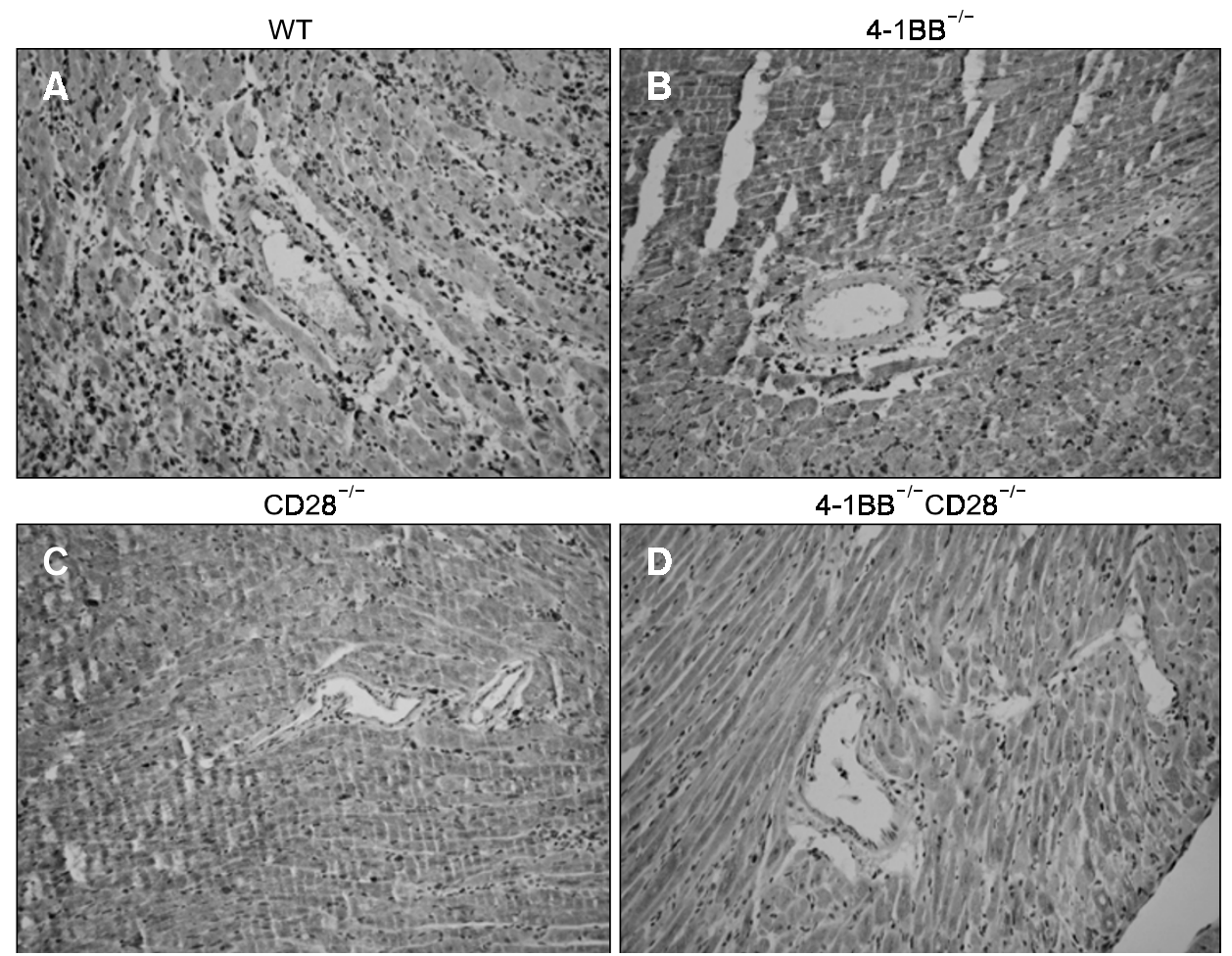

Figure 2. Immunostaining of cardiac allografts. Grafts were harvested at $7 \mathrm{~d}$ post transplantation. Sections of frozen allografts were stained with anti-CD3 as described in Materials and Methods.

tation showed that delayed rejection in the deficient mice correlates with less severe $T$ lymphocyte infiltration (Figure 2). Collectively, our results indicate that the long-term survival of cardiac allografts in CD28/4-1BB-deficient mice is due mainly to the absence of CD28 costimulatory signals.

We next performed an in vitro MLR to examine the responsiveness of $T$ cells to allostimulation. We stimulated WT, CD28-deficient, 4-1BB- deficient, and CD28/4-1BB-deficient Balb/c T cells with C57BL/6 APCs. There was no difference in the proliferative ability of alloantigen-stimulated T cells of WT and 41BB-deficient mice (Figure $3 \mathrm{~A}$ ). In contrast, proliferation of $T$ cells of CD28-deficient and CD28/41BB-deficient mice was markedly decreased compared with WT and 4-1BB-deficient mice. Even though the 4-1BB deficiency further decreased the proliferation induced by the CD28 deficiency $(P<$ 0.0049), it seemed that CD28 signals had a greater effect on proliferation than 4-1BB did in CD28/ 4-1BB-deficient mice (Figure 4A). Consistent with this conclusion, CD28-deficient and CD28/4-1BBdeficient mice had a comparable decrease in the production of IFN- $\gamma$ and IL-2 by T cells after allostimulation as compared with WT mice (Figure 3B, C). Our results suggest that the proliferation and cytokine secretion of alloreactive $T$ cells is dependent mainly on CD28 signals.

To determine the dependency of the allospecific
Ab response on $\mathrm{CD} 28,4-1 \mathrm{BB}$, or both signals, sera were collected at days $0,7,14,21$ and 28 after cardiac transplantation and cells derived from the donor strain (EL4 cells) were stained with the harvested sera. FACS analysis showed that allospecific IgG began to be detected in WT mice at day 14 and its levels reached a peak at day 21 and were decreased thereafter (Figure 4). 4-1BB-deficient mice produced similar levels of allospecific Ig $G$ during the first two weeks and thereafter its levels continued to increase and exceeded those of WT mice. In contrast to WT and 4-1BB-deficient mice, both CD28-deficient and CD28/4-1BB-deficient recipients produced basal levels of allospecific IgG (Figure 4). Taken together, our data indicate that the Ab response to alloantigens is dependent largely upon CD28 costimulatory signals. More importantly, the enhanced $A b$ response in 4-1BB-deficient mice is abolished in CD28/4-1BB-deficient mice, suggesting that 4-1BB signals do not make a significant contribution to the $A b$ response to alloantigens in the absence of CD28 signals.

Finally, we performed an in vivo CTL assay to examine the cytotoxic activity against alloantigens in WT, CD28-deficient, 4-1BB-deficient, and CD28/41BB-deficient mice. Figure 5 shows the extent of lysis of donor C57BL/6 splenocytes by Balb/c T cells $4 \mathrm{~h}$ after they had been transferred into the recipient. The strong CTL activity against target cells was 
A

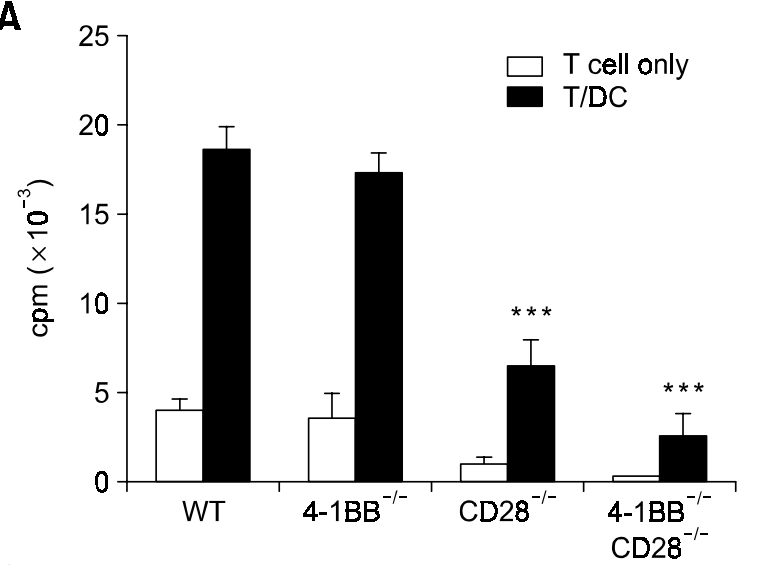

C

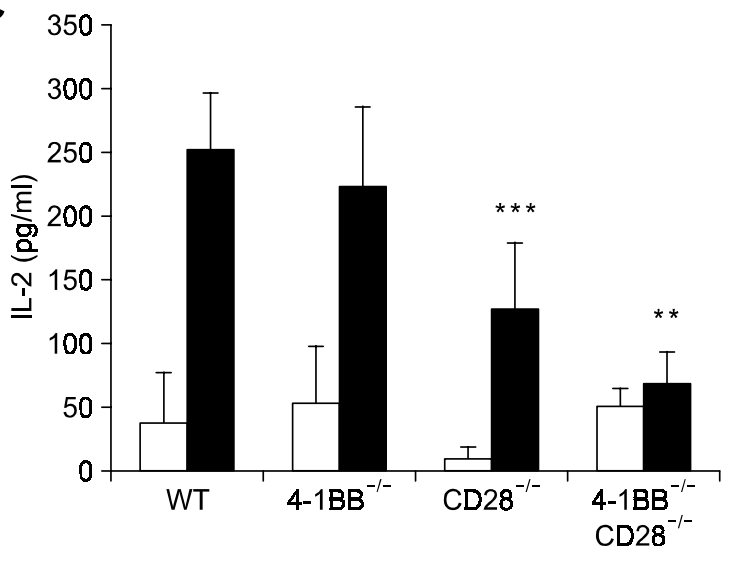

observed in WT T cells. Not unexpectedly, 4-1BBdeficient $T$ cells have comparable levels of CTL. CD28-deficient and CD28/4-1BB-deficient $T$ cells had a much lowest CTL activity compared with WT and 4-1BB-deficient mice. These results suggest that, like the antibody response, the role of $4-1 \mathrm{BB}$ signals is negligible in the absence of CD28 signals.

\section{Discussion}

An important question related to the 4-1BB study is whether 4-1BB costimulation is dependent on CD28 signals. Since $4-1 B B$ has a distinct signaling pathway from CD28 (Saoulli et al., 1998), and 4-1BB has a later role in sustaining the immune response (Cannon et al., 2001), it is believed that 4-1BB functions independently of CD28. In one model, however, 4-1BB stimulation enhances a cross-priming of CTL to tumor Ags only in the presence of intact CD28 signals (Diehl et al., 2002). Presumably, this is due to the requirement for prior upregulation of 4-1BB by both TCR stimulation and CD28 costimulation before 4-1BB functions. In this study, we demonstrated that despite their normal res-

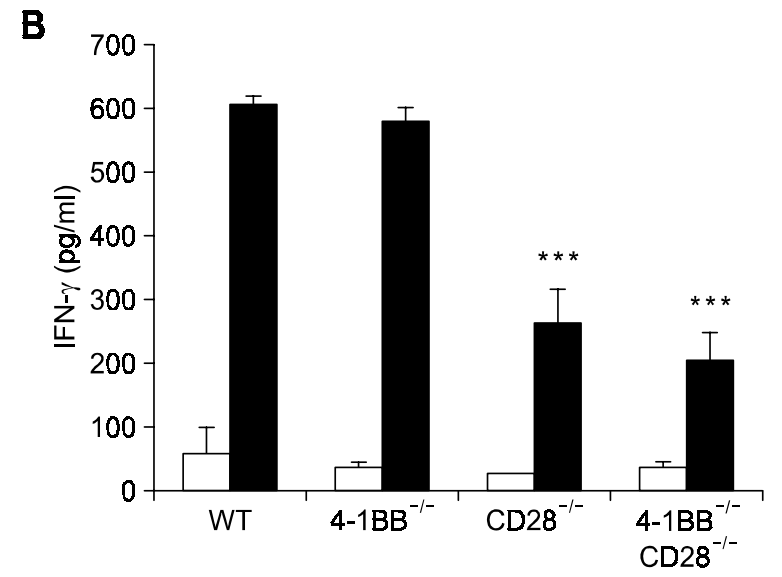

Figure 3. An in vitro MLR assay. (A) APCs were isolated from C57BL/6 mice and irradiated with $30 \mathrm{~Gy}$. The irradiated APCs $\left(5 \times 10^{5}\right.$ cells/well) were then cocultured for $3 \mathrm{~d}$ with T cells $\left(1 \times 10^{5}\right.$ cells/well) isolated from WT, CD28-, 4-1BB-, and CD28/4-1BB-deficient Balb/c mice. The cells were pulsed with $1 \mu \mathrm{Ci}\left[{ }^{3} \mathrm{H}\right.$ ]thymidine for the last $12 \mathrm{~h}$ of the the coculture period. $(\mathrm{B}, \mathrm{C})$ Production of cytokines in MLR culture. Experiments were set up as described above and the supernatants from cultures were collected $72 \mathrm{~h}$ after initiation of the culture and subjected to the measurement of IFN- $\gamma(\mathrm{B})$ and IL-2 (C) by ELISA. Data are shown as mean $\pm S D$ and are representative of three experiments.

ponsive ability to allostimulation (Figure 3), 4-1BBdeficient mice generated a more enhanced $A b$ and $a$ similar level of CTL response to alloantigens as compared with WT mice (Figures 4 and 5). More importantly, these immune responses of 4-1BB-deficient mice were abrogated in the absence of CD28 signals, suggesting that 4-1BB signals depend heavily upon CD28 signals.

Initial description of 4-1BB-deficient mice has shown that 4-1BB-deficient splenocytes were hyperresponsive with regard to proliferation when stimulated in vitro with plate-coated anti-CD3 (Kwon et al., 2002b). Recently, Croft's group has extended this observation by showing that 4-1BB-deficient $\mathrm{CD}^{+} \mathrm{T}$ cells have more enhanced responsiveness to a nominal antigen in vivo, which is not due to a developmental defect (Lee et al., 2005). However, they didn't observe any abnormal Ab response in 4-1BB-deficient mice. Our result seems to be contradictory to the observation by Croft's group in that even though WT and 4-1BB-deficient T cells have a similar extent of proliferation and cytokine secretion after allostimulation, 4-1BB-deficient mice display an enhanced $A b$ response to alloantigens. There exists several circumstantial evidence sup- 
A
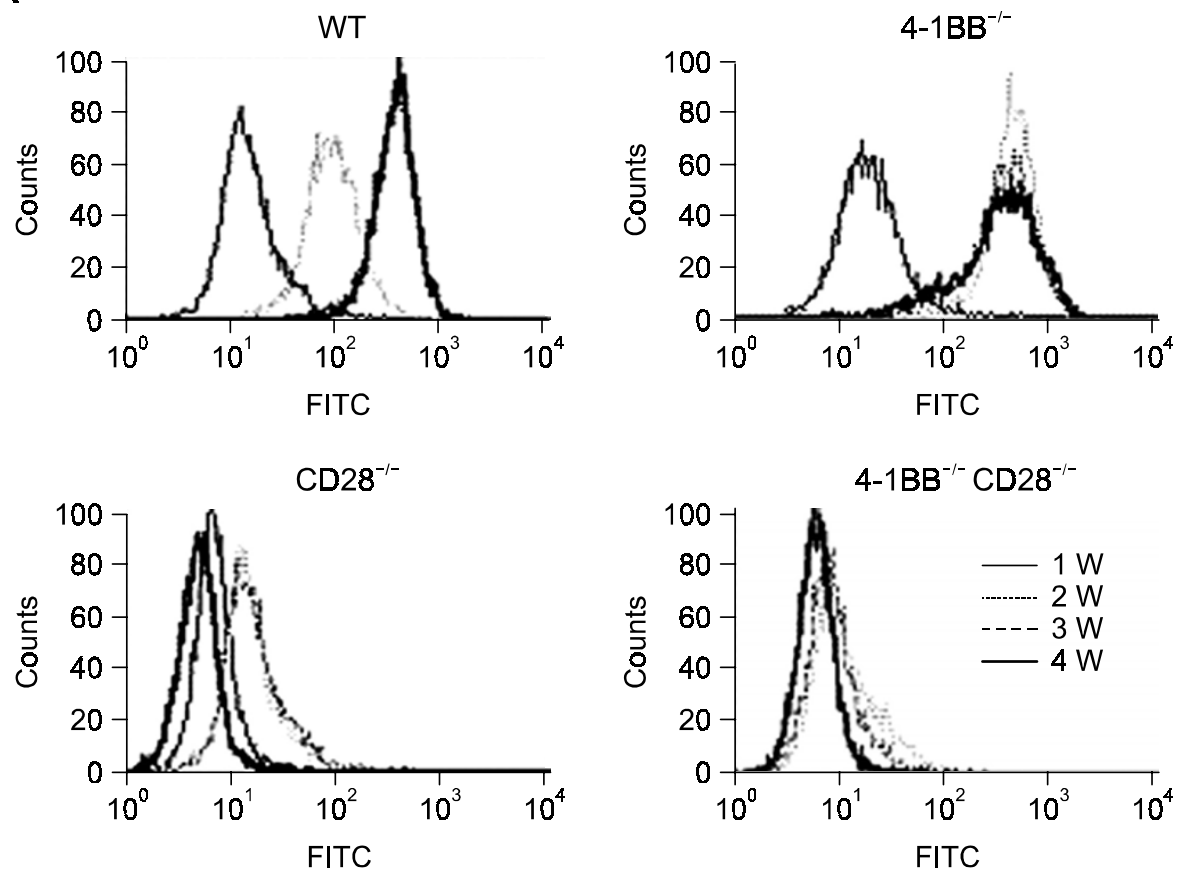

B

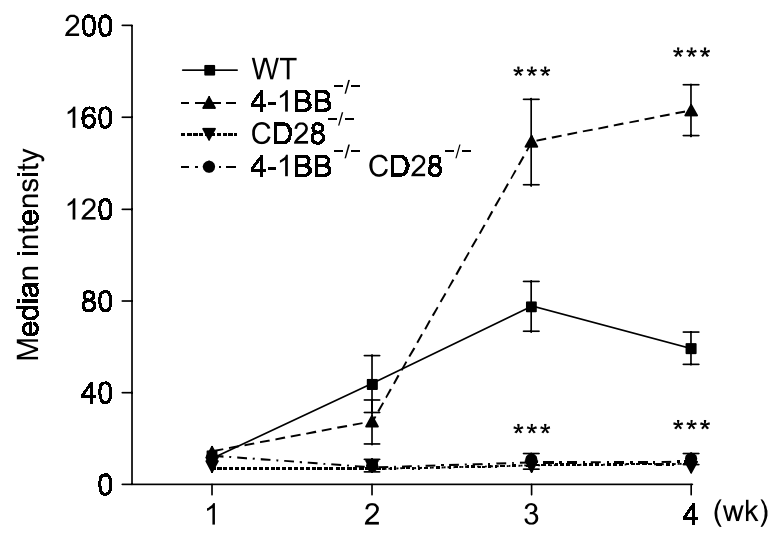

Figure 4. Alloantigen-specific Ab responses. Serum was harvested at weeks $0,1,2,3$, and 4 after cardiac transplantation. Levels of alloantigen-specific $A b$ were quantified by flow cytomery as described in Materials and Methods. (A) Representative FACS histograms. (B) Median intensity. Data are presented as mean \pm SEM ( $n=5-10$ per group). ${ }^{* \star *} P<$ 0.001 .

porting a higher $\mathrm{Ab}$ response in 4-1BB-deficient mice; 4-1BB-deficient mice have increased basal levels of Ig (Vinay et al., 2003). Moreover, blockage of interactions between 4-1BB and 4-1BBL elevates levels of autoantibody in cGVHD (Nozawa et al., 2001), whereas stimulation of 4-1BB abrogates $T$ cell-dependent Ab response (Mittler et al., 1999; Sun et al., 2002; Foell et al., 2003; Wu et al., 2003; Foell et al., 2004; Seo et al., 2004; Kim et al., 2005) and sustained stimulation of $4-1 B B$ in $4-1 B B L$ transgenic mice induces progressive depletion of $B$ cells and subsequent abrogation of Ab production (Zhu et al., $2000)$. It seems that 4-1BB signals are involved in Th1 immune responses (our unpublished data) and it has been shown that Th1-specific $A b$ responses are impaired in 4-1BB-deficient mice (Kwon et al., $2002 b)$. Conversely, it is possible that Th2-specific $\mathrm{Ab}$ responses would be elevated in 4-1BB-deficient mice particularly in conditions that $\mathrm{CD} 4^{+} \mathrm{T}$ cells are stimulated by strong Ags such as alloantigens (Lee et al., 2005). Therefore, we suspect that high levels of Th2-specific isotypes were responsible for the increased $\mathrm{Ab}$ response to alloantigens in 4-1BBdeficient mice that we observed in this study (Figure 4).

In vivo ligation of 4-1BB markedly elevate the effector function of $\mathrm{CD}^{+} \mathrm{T}$ cells by increasing their expansion and survival. It also can enhance $\mathrm{CD} 8^{+} \mathrm{T}$ cell immunity to poor immunogenic Ags (Halstead et al., 2002) and break $\mathrm{CD}^{+} \mathrm{T}$ cell tolerance (Wilcox et 
A
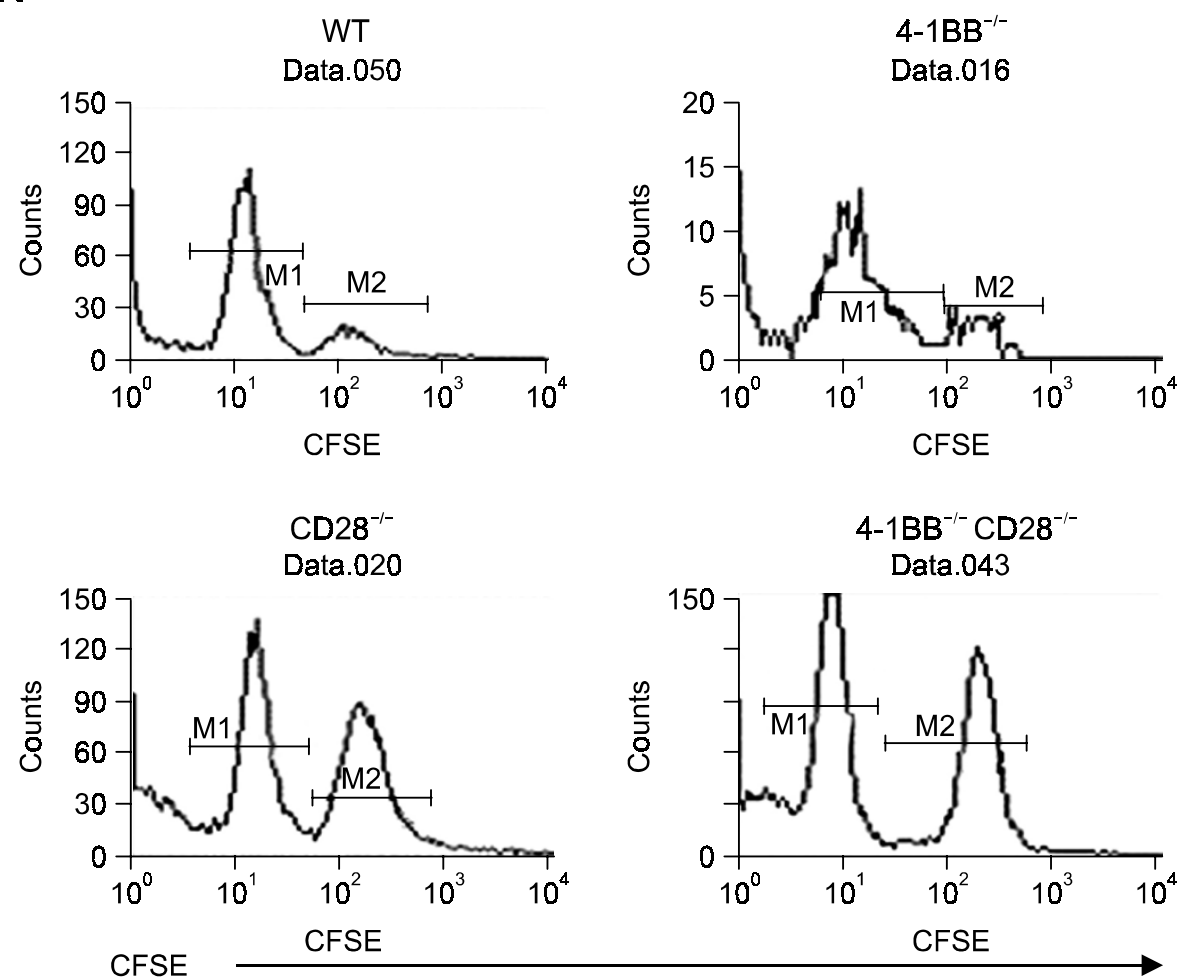

B

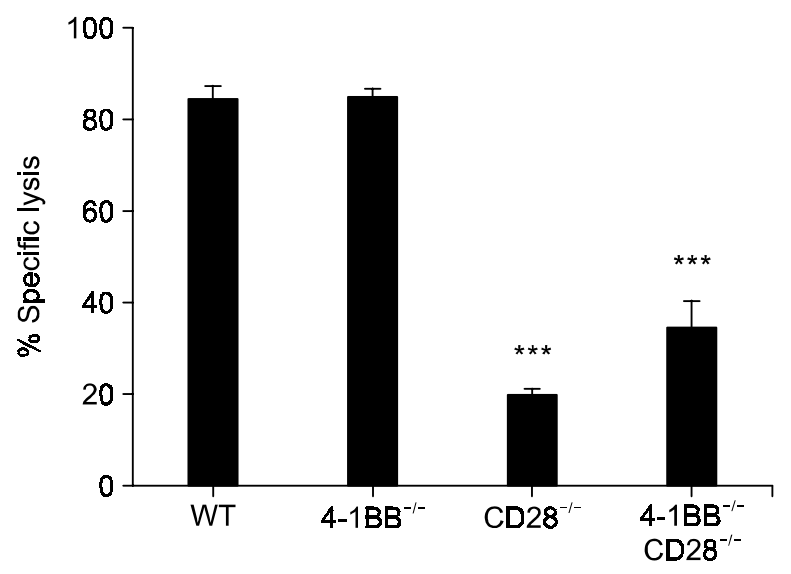

Figure 5. An in vivo CTL assay. An in vivo CTL assay was performed as described in Materials and Methods. (A) Representative FACS hitograms. (B) Specific lysis. Data are presented as mean \pm SEM ( $n=5$-10 per group). ${ }^{* * *} P<0.001$.

al., 2002; 2004). Surprisingly, 4-1BB-deficient and 4-1BBL-deficient mice had no or a minor defect in $\mathrm{CD}^{+} \mathrm{T}$ cell activity as compared with CD28-deficient mice (DeBenedette et al., 1999; Tan et al., 1999; Kwon et al., 2002b). Our present data are consistent with this observation. However, it is not known why a discrepancy exists depending on experimental models used. Collectively, our results reveal 4-1BB as a negative regulator for some aspects of alloimmune responses.

It is surprising that there was a significantly prolonged survival of cardiac allografts in 4-1BB-defi- cient mice as compared with WT mice, provided that these knockout mice have enhanced general immune responses to alloantigens. Further studies will be needed to solve this puzzling problem. Overall, the present study suggests that since 4-1BB signaling is dependent upon CD28 signaling, combined blockage of the two costimulatory molecules may not be an effective way to induce tolerance to allografts.

The dependency of 4-1BB signals on the CD28 costimulatory pathway implies that $4-1 B B$ plays a role downstream of CD28 signals in the process of $T$ cell activation. This may be because high levels of 
4-1BB expression on $T$ cells require TCR (T-cell receptor) triggering in combination with CD28 costimulation (Deihl et al., 2002). Provision of signals through 4-1BB results in increased survival and expansion of Ag-primed T cells (Cooper et al., 2002). Even though, in this study, we provided a possibility that 4-1BB signals depends on CD28 signals, we don't know the mechanism underlying our observations. Further studies will be needed to obtain a conclusive result regarding the hierarchy of costimulatory molecules, including 4-1BB and CD28.

\section{Acknowledgement}

This work was supported by grants from University of Ulsan (2005-0274) and the SRC Fund to the IRC from Korea Science and Engineering Foundation (KOSEF) and by a grant of the Korea Health 21 R\&D Project from the Ministry of Health \& Welfare (A040004).

\section{References}

Cannon JL, Ghumann B, DeBenedette MA, Yagita H, Okumura K, Watts TH. 4-1BB ligand induces cell division, sustains survival, and enhances effector function of CD4 and CD8 T cells with similar efficacy. J Immnol 2001:167:1313-24

Cho HR, Kwon B, Yagita H, La S, Lee EA, Kim JE, Akiba H, Kim J, Huh JH, Vinay DS, Ju SA, Kim BS, Mittler RS, Okumura $\mathrm{K}$, Kwon BS. Blockade of 4-1BB (CD137)/4-1BB ligand interactions increases allograft survival. Transplant Int 2004;17: 351-61

Coles RM, Mueller SN, Heath WR, Carbone FR, Brooks AG. Progression of armed CTL from draining lymph node to spleen shortly after localized infection with herpes simplex virus. J Immunol 2002;168:834-8

Cooper D, Bansal-Pakala P, Croft M. 4-1BB (CD137) controls the clonal expansion and survival of CD8 T cells in vivo but does not contribute to the development of cytotoxicity. Eur $\mathrm{J}$ Immunol 2002;32:521-9

Corry RJ, Winn HJ, Russel PS. Primary vascularized allografts of hearts in mice. Transplantation 1973;16:343-50

Dai Z, Konieczny BT, Baddoura FK, Lakkis FG. Impaired alloantigen-mediated $T$ cell apoptosis and failure to induce long-term allograft survival in IL-2-deficient mice. J Immunol 1998;161:1659-63

DeBenedette MA, Shahinian A, Mak TW, Watts TH. Costimulation of CD28 $\mathrm{T}$ lymphocytes by 4-1BB ligand. J Immunol $1997 ; 158: 551-9$

DeBenedette MA, Wen T, Bachmann MF, Ohashi PS, Barber BM, Stocking KL, Peschon JJ, Watts TH. Analysis of 4-1BB ligand (4-1BBL)-deficient mice and of mice lacking both 4-1BBL and $\mathrm{CD} 28$ reveals a role for $4-1 \mathrm{BBL}$ in skin allograft rejection and in the cytotoxic $T$ cell response to influenza virus. J Immunol 1999;163:4833-41
Diehl L, van Mierlo GJD, den Boer AT, van der Voort E, Fransen $M$, van Bostelen L, Krimpendfort P, Melief CJM, Mittler R, Toes REM, Offringa R. In vivo triggering through $4-1 \mathrm{BB}$ enables Th-independent priming of CTL in the presence of an intact CD28 costimulatory pathway. J Immunol 2002;168:3755-62

Foell J, Strahotin S, O'Neil SP, McCausland MM, Suwyn C, Haber M, Chander PN, Bapat AS, Yan XJ, Chiorazz N, Hoffmann MK, Mittler RS. CD137 costimulatory T cell receptor engagement reverses acute disease in lupus-prone NZB $x$ NZW $F_{1}$ mice. J Clin Invest 2003;119;1505-18

Foell J, Diez-Mendiondo BI, Diez OH, Holzen U, Ruck P, Bapat AS, Hoffmann MK, Mittler RS, Dannecker GE. Engagement of the CD137 (4-1BB) costimulatory molecule inhibits and reverses the autoimmune process in collage-induced arthritis and establishes lasting disease resistance. Immunology 2004;113:89-98

Futagawa T, Akiba H, Kodama T, Takeda K, Hosoda Y, Yagita $\mathrm{H}$, Okumura K. Expression and function of 4-1BB and 4-1BB ligand on murine dendritic cells. Int Immunol 2002;14:275-86

Goodwin RG, Din WS, Davis-Smith T, Anderson DM, Gimpol $\mathrm{SD}$, Sato TA, Maliszewski CR, Brannan Cl, Copeland NG, Jenkins NA, Farrah T, Armitage RT, Fanslow WC, Smith CA. Molecular cloning a ligand for the inducible T cell gene 4-1BB:a member of an emerging family of cytokines with homology to tumor necrosis factor. Eur J Immunol 1993; 23:2631-41

Hall BM. Cells mediating allograft rejection. Transplantation 1991;51:1141-51

Halstead ES, Mueller YM, Attman JD, Katsikis PD. In vivo stimulation of CD137 broadens primary antiviral $\mathrm{CD}^{+} \mathrm{T}$ cell responses. Nat Immunol 2002;3:536-41

Judge TA, Tang A, Spain LM, Deans-Gratiot J, Sayegh MH, Turka LA. The in vivo mechanisms of action of CTLA4lg. J Immunol 1996;156:2294-9

Kim EY, Lee EN, Lee J, Park HJ, Chang CY, Jung DY, Choi SY, Lee SK, Joh JW, Kim SJ. Two signal blockade with anti-CD45RB and anti-CD154 monoclonal antibodies inhibits graft rejection via CD4-dependent mechanisms in allogeneic skin transplantation. Exp Mol Med 2006;38:284-94

Kim J, Cho WS, La S, Suh JH, Kim BS, Cho HR, Kwon BS, Kwon B. Simulation with 4-1BB (CD137) inhibits chronic graft-versus-host disease by inducing activation-induced cell death of donor CD4 ${ }^{+}$T cells. Blood 2005;105:2206-13

Kim J, Choi WS, Kim HJ, Kwon B. Prevention of chronic graft-versus-host disease by stimulation with glucocorticoid-induced TNF receptor. Exp Mol Med 2006;38:94-9

Kim YJ, Kim SH, Mantel P, Kwon BS. Human 4-1BB regulates CD28 costimulation to promote Th1 cell responses. Eur J Immunol 1998;28:881-90

Kwon B, Moon CH, Kang S, Seo SK, Kwon BS. 4-1BB: still in the midst of darkness. Mol Cells 2000;10:119-26

Kwon B, Lee HW, Kwon BS. New insights into the role of 4-1BB in immune responses: beyond $\mathrm{CD}^{+} \mathrm{T}$ cells. Trends Immunol 2002a;23:378-80

Kwon B, Kim BS, Cho HR, Park JE, Kwon BS. Involvement of tumor necrosis factor receptor superfamily (TNFRSF) mem- 
bers in the pathogenesis of inflammatory disease. Exp Mol Med 2003;35:8-16

Kwon BS, Hurtado JC, Lee ZH, Kwak KB, Seo SK, Choi BK, Koller BH, Wolisi G, Broxmeyer HE, Vinay DS. Immune responses in 4-1BB (CD137)-deficient mice. J Immunol 2002b; 168:5483-90

Larsen CP, Pearson TC, Adams AB, Tso P, Shirasugi N, Strogert E, Anderson D, Cowan S, Price K, Naemura J, Emswiler J, Greene J, Turk LA, Bajorath J, Towsend R, Hagerty D, Linsley PS, Peach RJ. Rational development of LEA29Y (belatacept), a high-affinity variant of CTLA4-lg with potent immunosuppressive properties. Am J Transplant 2005;5:443-53

Lee S-W, Vella AT, Kwon BS, Croft M. Enhanced CD4 T cell responsiveness in the absence of 4-1BB. J Immunol 2005; $174: 6803-8$

Li Y, Li XC, Zheng XX, Wells AD, Turka LA, Strom TB. Blocking both signal 1 and signal 2 of T-cell activation prevents apoptosis of alloreactive T cells and induction of peripheral allograft tolerance. Nat Med 1999;5:1298-302

Lucas PJ, Negishi I, Nakayama K, Fields LE, Lo DY. Naïve CD28-deficient $T$ cells can initiate but not sustain an in vitro antigen-specific immune response. J Immunol 1995;154: 5757-68

Mittler RS, Bailey TS, Klussman K, Trailsmith MD, Hoffman MK. Anti-4-1BB monoclonal antibodies abrogate T cell-dependent humoral immune responses in vivo through the induction of helper T cell anergy. J Exp Med 1999;190:1535-40

Newell KA, He G, Guo Z, Kim O, Szot GL, Rulifson I, Zhou P, Hart Z, Thistlethwaite JR, Bluestone JA. Cutting edge: Blockade of the CD28/B7 costimulatory pathway inhibits intestinal allograft rejection mediated by $\mathrm{CD}^{+}$but not $\mathrm{CD} 8^{+} \mathrm{T}$ cells. J Immunol 1999;163:2358-62

Nozawa K, Ohta J, Sakurai J, Miyajima H, Yagita H, Okumura $\mathrm{K}$, Azuma M. Preferential blockade of $\mathrm{CD}^{+} \mathrm{T}$ cell responses by administration of anti-CD137 ligand monoclonal antibody results in differential effect on development of murine acute and chronic graft-versus-host diseas. J Immunol 2001;167: 4981-6

Pearson TC, Alexander DZ, Winn KJ, Linsley PS, Lowry RP, Larsen CP. Transplantation tolerance induced by CTLA4-Ig. Transplantation 1994;57:1701-6

Pollok KE, Kim Y-J, Hurtado J, Zhou Z, Kim KK, Kwon BS. 4-1BB $T$ cell antigen binds to mature $B$ cells and macrophages, and costimulates anti- $\mu$-primed splenic B cells. Eur J Immunol 1994;24:367-74

Rosenberg AS, Singer A. Cellular basis of skin allograft rejection: an in vivo model of immune-mediated tissue destruction. Annu Rev Immunol 1992;10:333-58

Rothstein DM, Sayegh MH. T-cell costimulatory pathways in allograft rejection and tolerance. Immunol Rev 2003;196: 85-108

Sakurai J, Ohata J, Saito K, Miyajima H, Kirano T, Kohsaka T, Enomoto S, Okumura K, Azuma M. Blockade of CTLA-4 signals inhibits Th2-mediated murine chronic graft-versus-host disease by an enhanced expansion of regulatory $\mathrm{CD} 8^{+} \mathrm{T}$ cells. J Immunol 2000;164:664-9
Saoulli K, Lee SY, Cannons JL, Yeh WC, Santana A, Goldstein MD, Bangia N, DeBenette MA, Mak TW, Choi Y, Watts TH. CD8-independent, TRAF2-dependent costimulation of resting T cells by 4-1BB ligand. J Exp Med 1998;187:1849-62

Sayegh MH, Akalin E, Hancock WW, Russell ME, Carpenter CB, Linsley PS, Turka LA. CD28-B7 blockade after alloantigenic challenge in vivo inhibits Th1 cytokines but spares Th2. J Exp Med 1995;181:1869-74

Schwartz RH. A cell culture model for T lymphocyte clonal anergy. Science 1990;248:1349-56

Seo SK, Choi JH, Kim YH, Kang WJ, Park HY, Suh JH, Choi BK, Vinay DS, Kwon BS. 4-1BB-mediated immunotherapy of rheumatoid arthritis. Nat Med 2004;10:1088-94

Sun Y, Lin X, Chen HM, Subudhi SK, Chen J, Koka R, Chen L, Fu YX. Costimulatory molecule-targeted antibody therapy of a spontaneous autoimmune disease. Nat Med 2002; 8:1405-13

Tan JT, Whitmire JK, Ahmed R, Pearson TC, Larsen CP. 4-1BB ligand, a member of the TNF family, is important for the generation of antiviral CD8 $\mathrm{T}$ cell responses. J Immunol 1999;163:4859-68

Tan JT, Ha J, Cho HR, Tucker-Burden C, Hendrix RC, Mittler RS, Pearson TC, Larsen CP. Analysis of expression and function of the costimulatory molecule 4-1BB in alloimmune responses. Transplantation 2000;70:175-83

Trambley J, Bingaman AW, Lin A, Elwood ET, Waitze SY, Ha J, Durham MM, Corbascio M, Cowan SR, Pearson TC, Larsen CP. Asialo GM1(+) T cells play a critical role in costimulation blockade-resistant allograft rejection. J Clin Invest 1999; 104:1715-22

Turka LA, Linsley PS, Lin H, Brady W, Leiden JM, Wei RQ, Gibson ML, Zheng XG, Myrdal S, Gordon D, Bailey J, Bolling SF, Thompson CB. T-cell activation by the CD28 ligand B7 is required for cardiac allograft rejection in vivo. Proc Natl Acad Sci USA 1992;89:11102-5

Vinay DS, Kwon BS. Role of 4-1BB in immune responses. Sem Immunol 1998;10:381-9

Vinay DS, Wolishi GO, Yu K-Y, Choi BK, Kwon BS. Immunity in the absence of CD28 and CD137 (4-1BB) molecules. Immunol Cell Biol 2003;81:176-84

Vincenti F, Larsen C, Durrbach A, Wekerle T, Nashan B, Blancho G, Lang P, Grinyo J, Halloran PF, solez K, Hagerty D, Levy E, Zho W, Natarajan K, Charpentier B for the Belatacept Study Group. Costimulation blockade with Belatacept in renal transplantation. N Engl J Med 2005;353:770-81

Wang J, Guo Z, Dong Y, Kim O, Hart J, Adams J, Larsen CP, Mittler RS, Newell KA. Role of 4-1BB in allograft rejection mediated by $\mathrm{CD} 8^{+} \mathrm{T}$ cells. Am J Transplant 2003;3:543-51

Wells AD, Li XC, Li Y, Walsh MC, Zheng XX, Wu Z, Nuzez G, Tang A, Sayegh M, Hancock WW, Strom TB, Turka LA. Requirement for T-cell apoptosis in the induction of peripheral transplantation tolerance. Nat Med 1999;5:1303-7

Wilcox RA, Chapoval Al, gorski KS, Shin T, Flies DB, Tamada K, Mittler RS, Tsuchiya H, Pardoll DM, Chen L. Cutting edge: Expression of functional CD137 receptor by dendritic cells. J Immunol 2002a;168:4262-7 
Wilcox RA, Flies DB, Zhu G, Johnson AJ, Tamada K, Chapoval Al, Strome SZ, Pease LR, Chen L. Provision of antigen and CD137 signaling breaks immunological ignorance, promoting regression of poorly immunolgenic tumors. J Clin Inves 2002b;109:651-9

Wilcox RA, Tamada K, Flies DB, Zhu G, Chapoval Al, Blazar $B R$, Kast WM, Chen L. Ligation of CD137 receptor prevents and reverses established anergy of $\mathrm{CD} 8^{+} \mathrm{T}$ cytolytic T lymphocytes in vivo. Blood 2004;103:177-84
Wu ZQ, Khan AQ, Shen Y, Wolcott KM, Dawicki W, Watts TH, Mittler RS, Snapper CM. 4-1BB (CD137) differentially regulates murine in vivo protein- and polysaccharide-specific immunoglobulin isotype responses to Streptococcus pneumoniae. Infec Immun 2003;71:196-204

Zhu G, Flies DB, Tamada K, Sun Y, Rodriquez M, Fu YX, Chen L. Progressive depletion of peripheral B lymphocytes in 4-1BB (CD137) ligand/l- $E_{\alpha}$-transgenic mice. J Immunol 2000;167: 2671-6 